\title{
Rediscovery of Glauconycteris superba Hayman, 1939 (Chiroptera: Vespertilionidae) after 40 years at Mbiye Island, Democratic Republic of the Congo
}

\author{
Guy-Crispin GEMBU TUNGALUNA ${ }^{1}$, Victor VAN CAKENBERGHE ${ }^{2}$, \\ Prescott MUSABA AKAWA ${ }^{3}$, Benjamin DUDU AKAIBE ${ }^{4}$, Erik VERHEYEN ${ }^{5}$, \\ Frits DE VREE ${ }^{6} \&$ Jakob FAHR ${ }^{7}$ \\ ${ }^{1,3,4}$ LEGERA, Faculté des Sciences, Université de Kisangani, B.P. 2012 Kisangani, DRC. \\ ${ }^{2,6}$ Functional Morphology Group, Department of Biology, Universiteit Antwerpen, \\ Campus Drie Eiken, Universiteitsplein 1, B-2610 Antwerpen (Wilrijk), Belgium. \\ ${ }^{5}$ Evolutionary Ecology Group, Department of Biology, Universiteit Antwerpen, \\ Groenenborgerlaan 171, B-2020 Antwerpen, Belgium \\ ${ }^{5}$ Vertebrate Department, Royal Belgian Institute of Natural Sciences, \\ Vautierstraat 29, B-1000 Brussel, Belgium \\ ${ }^{7}$ Division of Evolutionary Biology, Zoological Institute, TU Braunschweig, Mendelssohnstr. 4, \\ D-38106 Braunschweig, Germany \\ Emails: ${ }^{1}$ gembuguy@yahoo.fr, ${ }^{2}$ victor.vancakenberghe@ua.ac.be (corresponding author) \\ ${ }^{3}$ prescottmusaba@yahoo.fr, ${ }^{4}$ duduakaibe@yahoo.fr, ${ }^{5}$ erik.verheyen@naturalsciences.be, \\ ${ }^{6}$ frits.devree@ua.ac.be, ${ }^{7}$ jakob.fahr@gmail.com
}

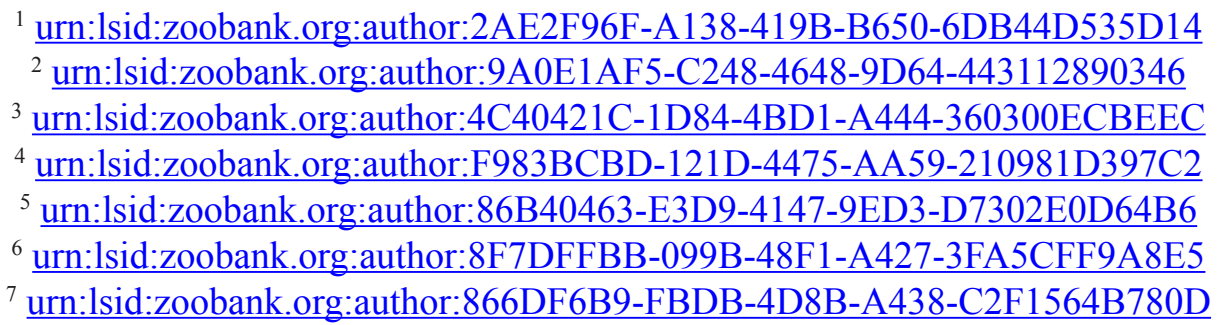

\begin{abstract}
We report the rediscovery of the Pied Butterfly Bat, Glauconycteris superba Hayman, 1939, 40 years after this species was last recorded. The new specimen from Mbiye Island, Democratic Republic of the Congo, is compared with the type specimens of G. s. superba and G. superba sheila Hayman, 1947 and a specimen from Matonguiné, Ivory Coast. The variation in the striking colouration of the pelage as well as in morphometric data is considered to be individual rather than geographic variation and we tentatively regard G. s. sheila as a synonym of the nominate form. Despite the wide distribution of this species in the tropical forest zone of West and Central Africa, only four specimens from four localities are known to date, which might indicate very specific habitat preferences. Contemporary land cover information around historic collection sites shows degraded landscapes. Given the highly uncertain area of occupancy of this species, we suggest changing the status of G. superba in the IUCN Red List of Threatened Species from "Least Concern" to "Data Deficient".
\end{abstract}

Key words. Bats, morphometrics, taxonomy, distribution, conservation. 
Gembu Tungaluna G.-C., Van Cakenberghe V., Musaba Akawa P., Dudu Akaibe B., Verheyen E., De Vree F. \& Fahr J. 2013. Rediscovery of Glauconycteris superba Hayman, 1939 (Chiroptera: Vespertilionidae) after 40 years at Mbiye Island, Democratic Republic of the Congo. European Journal of Taxonomy 42: 1-18. http://dx.doi. org/10.5852/ejt.2013.42

\section{Introduction}

Glauconycteris superba Hayman, 1939, the Pied or Superb Butterfly Bat, is one of the most spectacularly coloured bats found in Africa. It is the largest species of the genus and characterised by black wings and a predominantly black pelage, which is strikingly marked with white spots and stripes on the head, back and belly.

Despite this unique and conspicuous colouration, only two additional specimens had been collected since its discovery in 1938 in Pawa, Democratic Republic of the Congo (DRC): one on 6 Dec. 1946 in Oda, southern Ghana (and designated as type of Glauconycteris superba sheila Hayman, 1947), and one on 24 Jan. 1972 in Matonguiné [sometimes spelled as Matongouiné], southwestern Ivory Coast (Fahr 2013). In this paper we report on a fourth specimen, constituting the rediscovery of this species after 40 years since the last record, present data on its morphology and distribution, characterize climatic and land cover conditions at the collection sites, and discuss the taxonomy and conservation status of G. superba.

\section{Material and Methods}

\begin{tabular}{|c|c|c|}
\hline \multicolumn{3}{|c|}{ Abbreviations used in text and figures } \\
\hline $3 \mathrm{ph} 1$ & $=$ & length of first phalanx of third finger \\
\hline $3 \mathrm{ph} 2$ & $=$ & length of second phalanx of third finger \\
\hline $3 \mathrm{ph} 2+3$ & $=$ & length of combined second and third phalanges of third finger \\
\hline 4ph1 & $=$ & length of first phalanx of fourth finger \\
\hline $4 \mathrm{ph} 2$ & $=$ & length of second phalanx of fourth finger \\
\hline $5 \mathrm{ph} 1$ & $=$ & length of first phalanx of fifth finger \\
\hline $5 \mathrm{ph} 2$ & $=$ & length of second phalanx of fifth finger \\
\hline ad & $=$ & adult \\
\hline alc & $=$ & alcoholic or fluid-preserved specimen \\
\hline BBUL & $=$ & width between the auditory bullae \\
\hline $\mathrm{BcH}$ & $=$ & height of braincase \\
\hline $\mathrm{BDA}$ & $=$ & Benjamin Dudu Akaibe \\
\hline $\mathrm{Bm}$ & $=$ & body mass \\
\hline $\mathrm{BMNH}$ & $=$ & Natural History Museum, London \\
\hline Brain & $=$ & width of braincase \\
\hline CBL & $=$ & condylobasal length to base of incisor \\
\hline $\mathrm{CBL}+$ & $=$ & condylobasal length to tip of incisor \\
\hline CBLC & $=$ & condylobasal length to base of canine \\
\hline $\mathrm{CBLC}+$ & $=$ & condylobasal length to tip of canine \\
\hline $\mathrm{C}-\mathrm{C}$ & $=$ & width across the upper canines \\
\hline $\mathrm{C}-\mathrm{M}^{3}$ & $=$ & length of maxillary toothrow \\
\hline $\mathrm{C}-\mathrm{M}_{3}$ & $=$ & length of mandibular toothrow \\
\hline Conang & $=$ & distance between condylar and angular processes \\
\hline Concor & $=$ & distance between condylar and coronoid processes \\
\hline Cor & $=$ & height at the coronoid process \\
\hline $\mathrm{DRC}$ & $=$ & Democratic Republic of the Congo \\
\hline Ear & $=$ & ear length \\
\hline
\end{tabular}




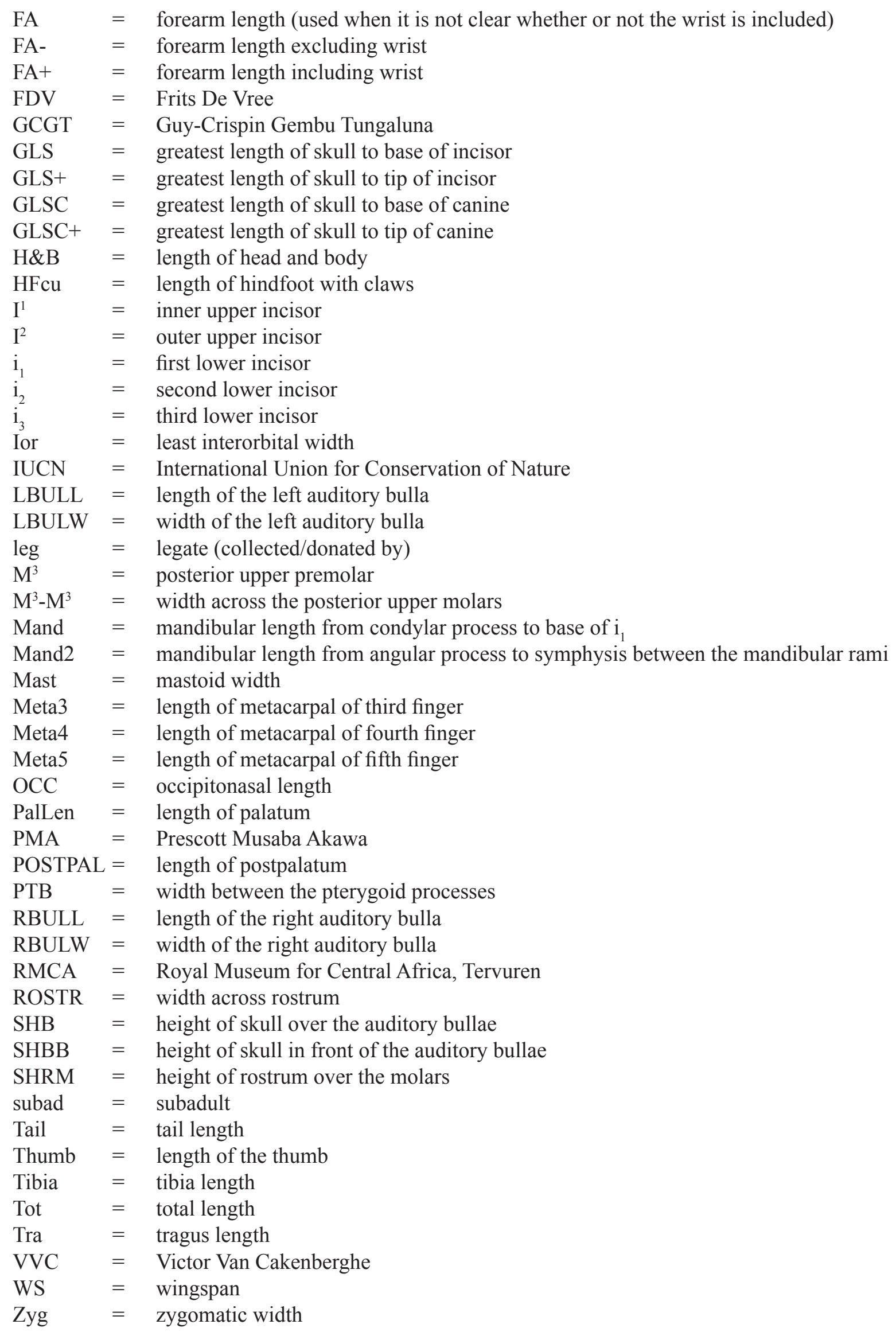




\section{Study site}

Field work was conducted at Mbiye, an island situated in the Congo River opposite the city of Kisangani (Fig. 1). In 2012, the LEGERA team (GCGT, PMA, BDA) deployed ten mist nets (10 m x $2.5 \mathrm{~m}$, mesh $20 \mathrm{~mm}$ ) for five nights each month from January to June.

Mbiye Island is located in the Guineo-Congolian lowland forests of the Congo River basin. Dominant tree species on the island are Coelocaryon botryoides Verm., Gilbertiodendron dewevrei (De Wild) J. Leonard and Scorodophloeus zenkeri Harms (Fabaceae). In the immediate vicinity of the mistnet where the Glauconycteris specimen was collected, we recorded the following tree species: Agelaea pentagyna (Lam.) Baill. (Connaraceae), Berlinia grandiflora (Vahl) Hutch. and Dalziel (Fabaceae), Coelocaryon preussii Warb. (Myristicaceae), Cola digitata Mast. (Malvaceae), Drypetes bipindensis (Pax) Hutch. (Putranjivaceae), Pterygota bequaertii De Wild. (Malvaceae), and Trilepisium madagascariense DC. (Moraceae) (for plant identification, see Lejoly et al. 2010; for details on the Mbiye Island, see Nshimba 2008). The natural vegetation of lowland wet forest has been variably degraded on Mbiye Island to secondary forest and fallow land ("jachères") by human land use.

\section{Specimens examined}

Besides the new specimen, two additional specimens in the collection of the Royal Museum for Central Africa (RMCA, Tervuren, Belgium) were examined, and photos of the specimen in the collection of the Natural History Museum (BMNH), London, were made available for comparison. Age was determined based on the ossification of the epiphyses of the wing bones. Details of the specimens are given in the Appendix.

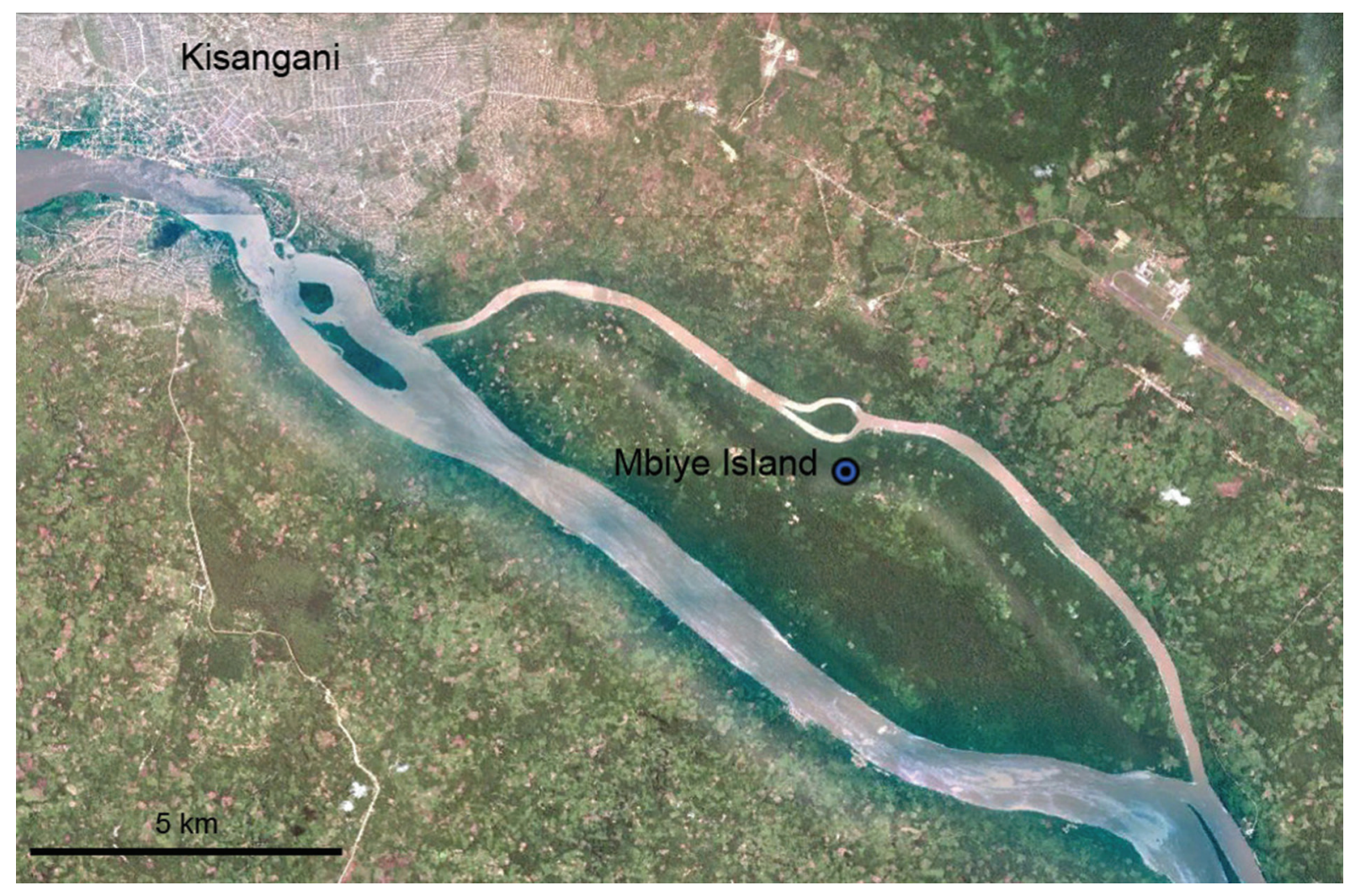

Fig. 1. Satellite image of the study area Mbiye Island, DRC (map data (C 2012 Google \& GeoEye). The blue point shows the collection locality of G. superba Hayman, 1939. 


\section{Measurements}

In the field, eight external measurements were taken by GCGT. Bm was measured with a spring balance (Pesola; accuracy $1 \mathrm{~g}$ ). WS was measured with a ruler (accuracy $1 \mathrm{~mm}$ ). The other measurements were taken using digital callipers (Mitutoyo; accuracy $0.05 \mathrm{~mm}$, rounded to $0.1 \mathrm{~mm}$ ): FA, Ear, Tail, Tra, Tot and Tibia.

Measurements by FDV were taken using a dial callipers (Helios; accuracy $0.05 \mathrm{~mm}$, rounded to $0.1 \mathrm{~mm}$ ). Independent measurements were taken by VVC on the specimens available at the RMCA using dial callipers (Helios; accuracy $0.05 \mathrm{~mm}$, rounded to $0.1 \mathrm{~mm}$ ). Craniodental measurements include GLS, GLS+, GLSC, GLSC+, CBL, CBL+, CBLC, CBLC+, OCC, Ior, Zyg, Mast, Brain, SHB, SHBB, ROSTR, C-M ${ }^{3}$, C-C, $\mathrm{M}^{3}-\mathrm{M}^{3}$, PalLen, POSTPAL, PTB, BBUL, LBULL, LBULW, RBULL, RBULW, Mand, C-M 3 , Mand2, Conang, Concor, and Cor. The external measurements comprise FA+, FA-, Meta3, 3ph1, 3ph2+3, Meta4, 4ph1, 4ph2, Meta5, 5ph1, 5ph2, Tibia, Ear, Tra, Tail, H\&B, Thumb, HFcu.

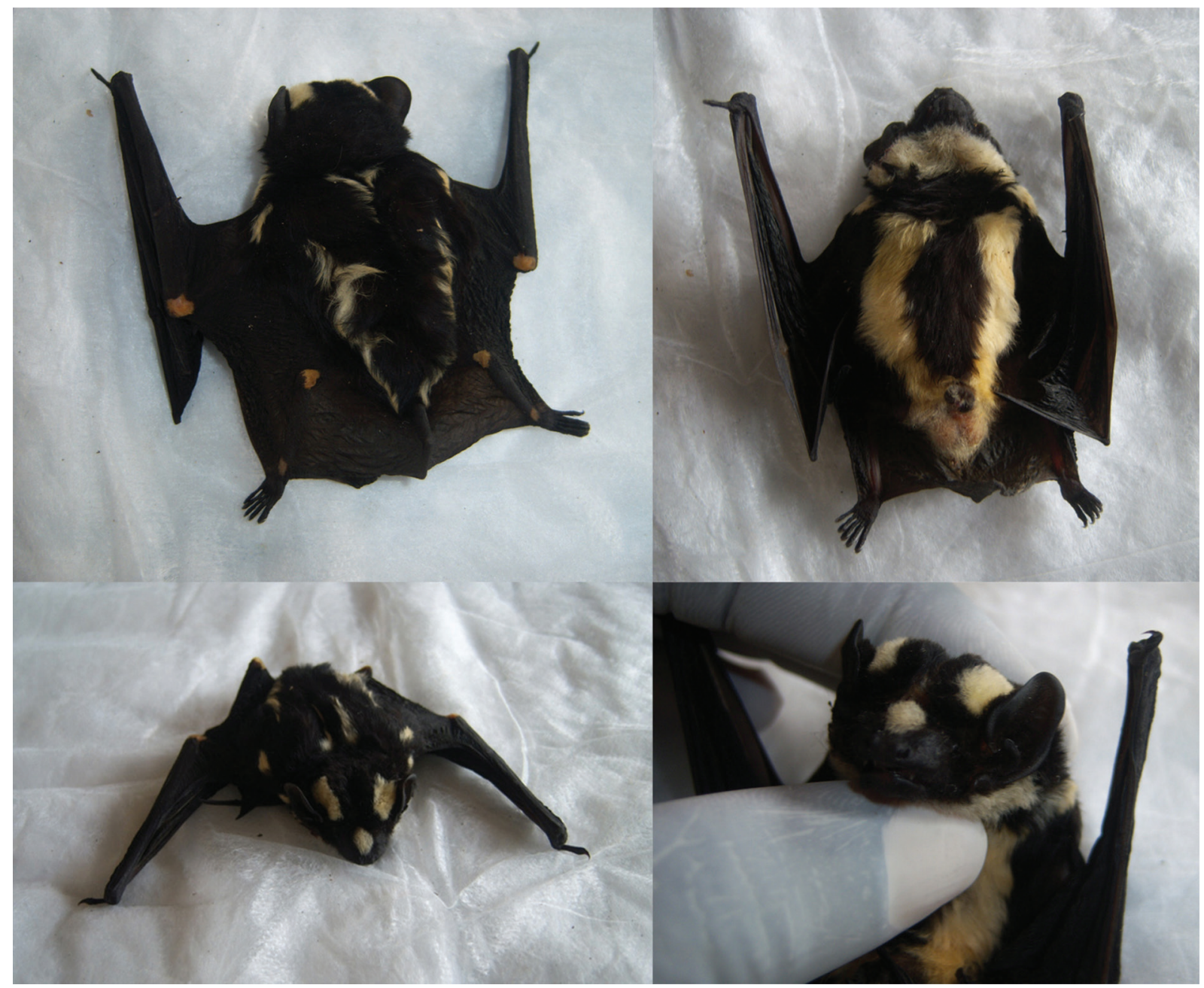

Fig. 2. Pelage pattern of the freshly collected Glauconycteris superba Hayman, 1939 specimen from Mbiye Island (RMCA a1.097-M-3153). Upper left: dorsal view, upper right: ventral view, lower left: anterior-dorsal view, lower right: detail of head and breast. 


\section{Results}

Order Chiroptera Blumenbach, 1779

Family Vespertilionidae Gray, 1821

Subfamily Vespertilioninae Gray, 1821

Genus Glauconycteris Dobson, 1875

Glauconycteris superba Hayman, 1939

On $19 \mathrm{Feb}$. 2012, one of ten mistnets was set up in secondary forest on the island, near a clearing where crops were cultivated. During this session (from 18:00 to 06:00) one adult male Glauconycteris superba (Fig. 2) entered the net between 19:00 and 20:00, and was captured alongside a Megaloglossus woermanni Pagenstecher, 1885, a Rhinolophus landeri Martin, 1838, and a Casinycteris argynnis Thomas, 1910. The Glauconycteris specimen was preserved in $90 \%$ ethanol and deposited in the collections of the RMCA, where the skull was extracted and cleaned.

\section{Morphological comparison of the four specimens}

Figure 3 shows the variation in the white spots among the different specimens. Unfortunately, the specimen from Matonguiné has suffered major damage as it had been dried out for an extended period of time, which resulted in loss of fur and decolouration of the remaining pelage. Still, it is possible to

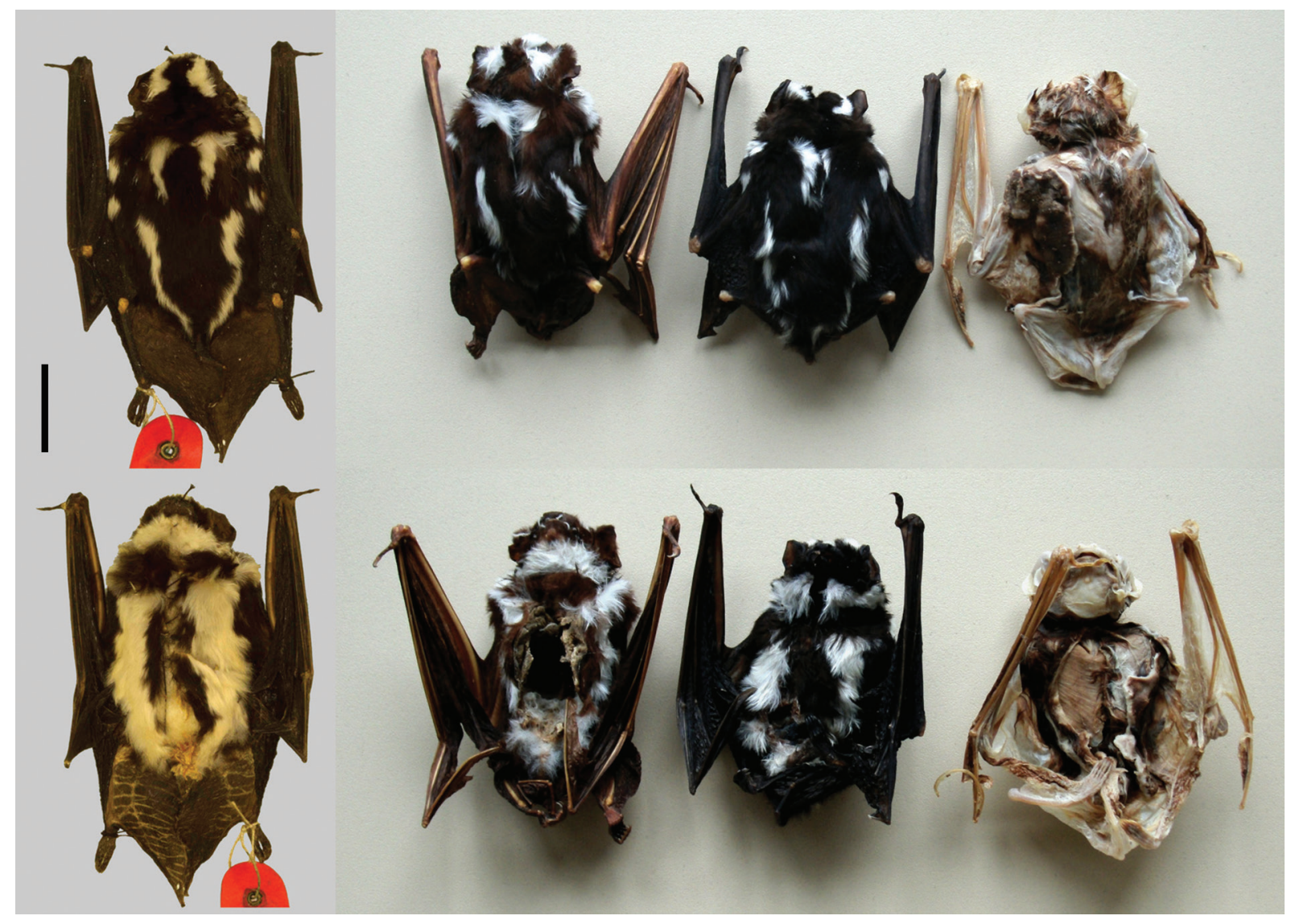

Fig. 3. Pelage pattern of the four known specimens of Glauconycteris superba Hayman, 1939 (upper row: dorsal, lower row: ventral). From left to right: holotype of G. s. sheila Hayman, 1947 (BMNH 47.10), holotype of G. superba (RMCA 14765), new specimen from Mbiye Island (RMCA a1.097-M-3153), and the specimen from Matonguiné (RMCA 97.077-M-7719). Scale bar $=2 \mathrm{~cm}$. 
distinguish the white spots on the belly and the head. Drawings of the head made shortly after the time of collection (Fig. 4), illustrate that spots on the head of this specimen were almost identical to those of the other specimens. Among the three remaining specimens, the Mbiye specimen is the darkest, but Hayman $(1939,1947)$ described his two type specimens as being black, so probably their pelages have faded over the years. Hayman (1947) also indicated that the type specimen of G. s. sheila differed from the type of G. s. superba in having "conspicuous unpigmented areas on the upper surface of the elbow, knee and ankle joints", suggesting a different colour pattern of G. s. superba. However, as illustrated in Fig. 3, these unpigmented areas are definitely present on the knees, but not as obvious on the elbows, although the paler colour of the arms might blur this. In the new specimen, these pale areas are present on elbows, knees, and ankles.

The various white spots exhibit some individual variation. The two lateral white bands on the belly are widest in the type of G. s. sheila, followed by the Mbiye specimen, and narrowest in the type of G. $s$. superba. However, since a major part of the belly was removed from the latter specimen, the width of the bands might be underestimated.

The white spot on the throat varies not as much in its width as in the extension to the sides of the head, where it may or may not become visible on the dorsal side. In Fig. 3, it appears as if the specimen from Mbiye has a divided throat spot, but this is due to the fact that the throat was cut open to remove the skull.

The three white spots on the head - one median on the nose and two on the crown of the head near the bases of the ears - also show some variation in size, especially the ear spots.

The largest spots on the back are fairly similar in all three specimens. The two spots between the shoulders are widest near the head and tapering to the middle of the back. In the type of G. s. sheila, the distance between the two spots seems to be much wider than in the two other specimens, but this is an artefact due to the position of the shoulder blades, which are fixed close to each other in the latter specimens, thereby concealing the connecting skin in a cavity. From the middle of the back, about the height where the two anterior spots end, two bands run to the lower back where they nearly meet. These two mid-back bands diminish in width from the anterior to the posterior side. In the specimen from Mbiye, the two bands seem to be subdivided in multiple spots, but this is due to the orientation of the individual hairs on the photo, where they are stretched to the sides of the body and not along the length of the body as for the other specimens.

The major difference, however, is in the position, size and number of spots between the mid-back shoulder spots and the neck region. In the two Congolese specimens, only two spots are present on each side, whereas the type of G. s. sheila and the specimen from Matonguiné have three. These extra spots were already reported by Hayman (1947). Hayman links the anterior-most spots with the white belly
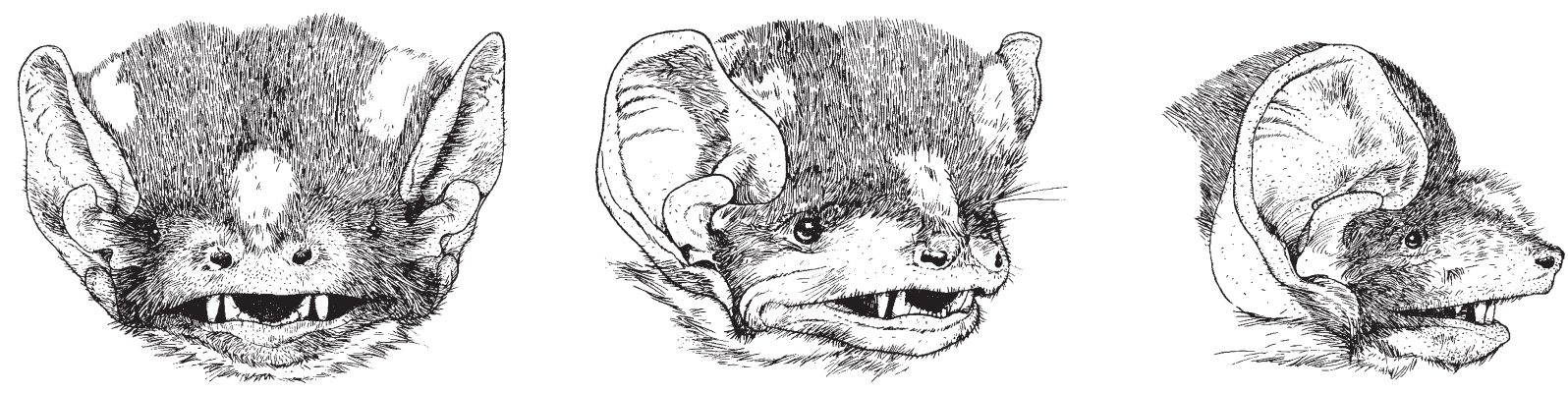

Fig. 4. Head of Glauconycteris superba Hayman, 1939 from Matonguiné (RMCA 97.077-M-7719). 
bands, which end just in front of the spots (see also Cansdale's photo in Nowak 1999). In the type of G. s. superba, the anterior spots seems to run into belly bands, but in the Mbiye specimen, these ventral bands do not reach as far anteriorly. Here the throat spot reaches slightly further towards the anterior spot of the back. So the anterior-most spots on the back might possibly form a connection with either the belly or the throat spots on the ventral side.

For the specimen from Mbiye, Fig. 3 also shows on the anterior side of the mid-back bands a slight separation between the main part of these bands and its anterior-most part (again depending on how the individual hairs are combed). If more dark hairs were present, this could lead to a split off of the anteriormost part of the mid-back bands. This split-off spot would then be almost similar to the posterior-most small spot found in the type of G. s. sheila, although in the latter specimen this spot is slightly more laterally positioned.

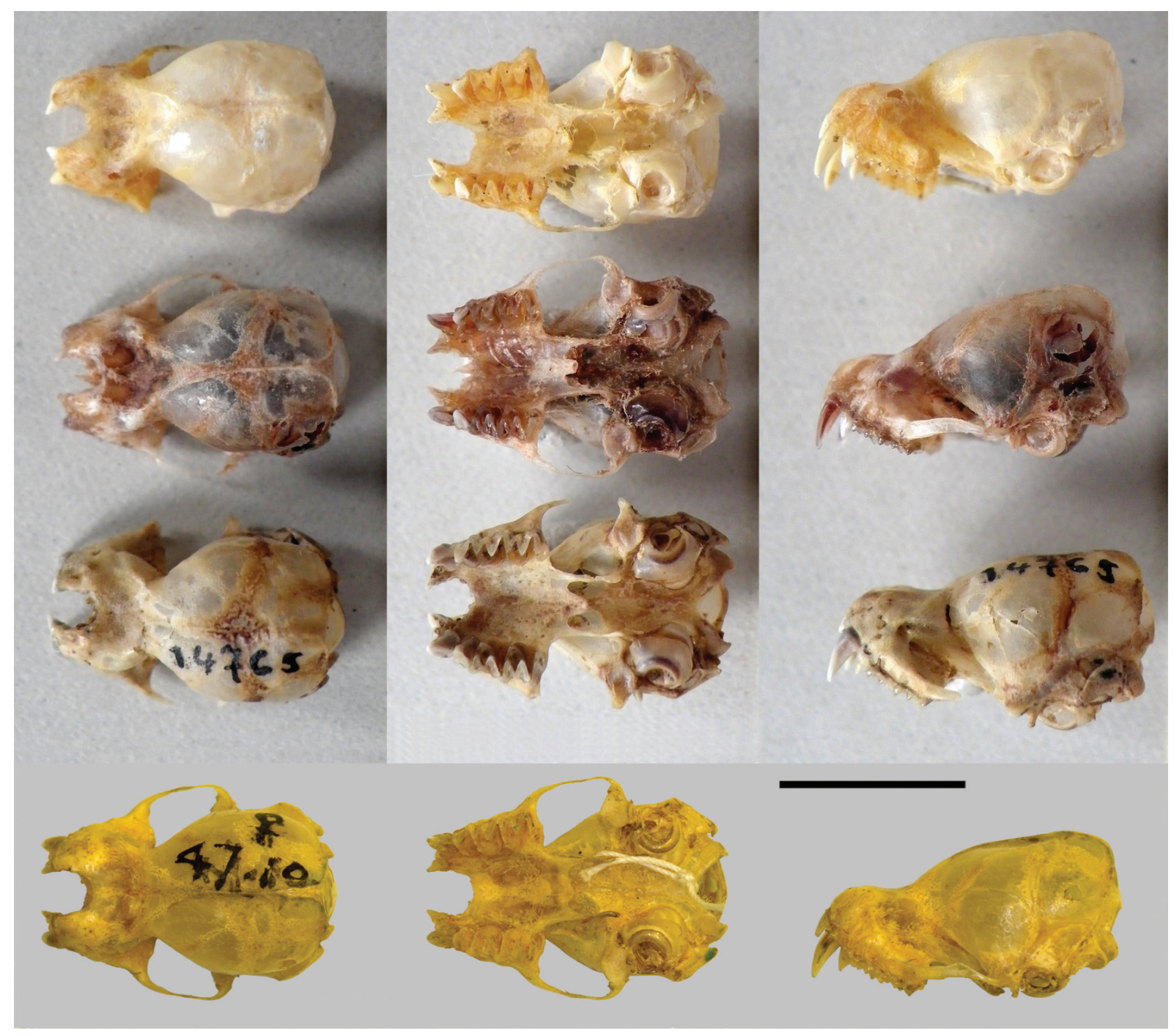

Fig. 5. Crania of the four known specimens of Glauconycteris superba Hayman, 1939 (left row: dorsal, middle row: ventral; right row: lateral). From top to bottom: specimen from Matonguiné (RMCA 97.077M-7719, §), Mbiye Island (RMCA a1.097-M-3153, §), holotype of G. superba (RMCA 14765, ?), and holotype of G. s. sheila Hayman, 1947 (BMNH 47.10, ,). Scale bar $=1 \mathrm{~cm}$ 
The skulls are very similar in size and shape (Tabs 1-2, Figs 5-6) although the type of G. s. superba is clearly subadult as indicated by the incompletely fused epiphyses of the wing bones. All skulls show a marked angle at the junction between rostrum and braincase as mentioned by Hayman $(1939,1947)$. Hayman (1947) also noted that the posterior upper molar $\left(\mathrm{M}^{3}\right)$ is considerably reduced. This is indeed the case for all four of the skulls, and most pronounced in the specimen from Matonguiné. All skulls have weak sagittal and lambdoidal crests, which are least developed in the type of G. s. superba and most developed in the type of G. s. sheila. The lack of crest development in the type of G. s. superba is probably age-related. Another character mentioned by Hayman (1939) is the presence of the minute accessory cusplet near the cingulum of the inner upper incisor $\left(\mathrm{I}^{1}\right)$. The development of this cusplet is variable, being most pronounced in the type of G. s. sheila and least in the specimen from Mbiye. The position of the outer upper incisor $\left(\mathrm{I}^{2}\right)$, described by Hayman (1939) as being "closely crowded between $\mathrm{I}^{1}$ and the canine", is indeed very crowded in both type specimens, but this is less the case in the two other specimens. The lower incisors are closely crowded as mentioned by Hayman (1939), and have three cusps. The inner incisors are more or less rectangular in shape, whereas $i_{2}$ and $i_{3}$ are more triangular.

\section{Morphometric comparison of the four specimens}

When based on the collector's measurements, the specimen from Mbiye Island has a considerably shorter forearm (FA) and Tibia compared to published values (Tab. 1). The comparatively small forearm initially challenged our identification of the Mbiye specimen as $G$. superba since the FA is given variably in the literature as $47 \mathrm{~mm}$ (Hayman \& Hill 1971), greater than $44.0 \mathrm{~mm}$ (Peterson \& Smith 1973), and $45 \mathrm{~mm}$ (Rambaldini 2010). However, these differences might be partially explained by individual measurement techniques. Therefore the three specimens currently available at the RMCA were measured again (Tabs 2-3).

The skull measurements of the three specimens in the RMCA are very similar (Tab. 2). Externally, the dimensions of the new specimen fit very well with those of the specimen from Matonguiné, with the exception of Tail length, but this is primarily due to the fact that the tail could not be completely stretched. The tail length appears to be very similar to that of the type from Pawa, but in the latter specimen the point of origin of the tail could not be determined as the abdominal region (including the genital area) had been completely removed during preparation. Considering that the type is subadult, it is remarkable that its long bones (FA and metacarpals) are much larger than the corresponding bones in

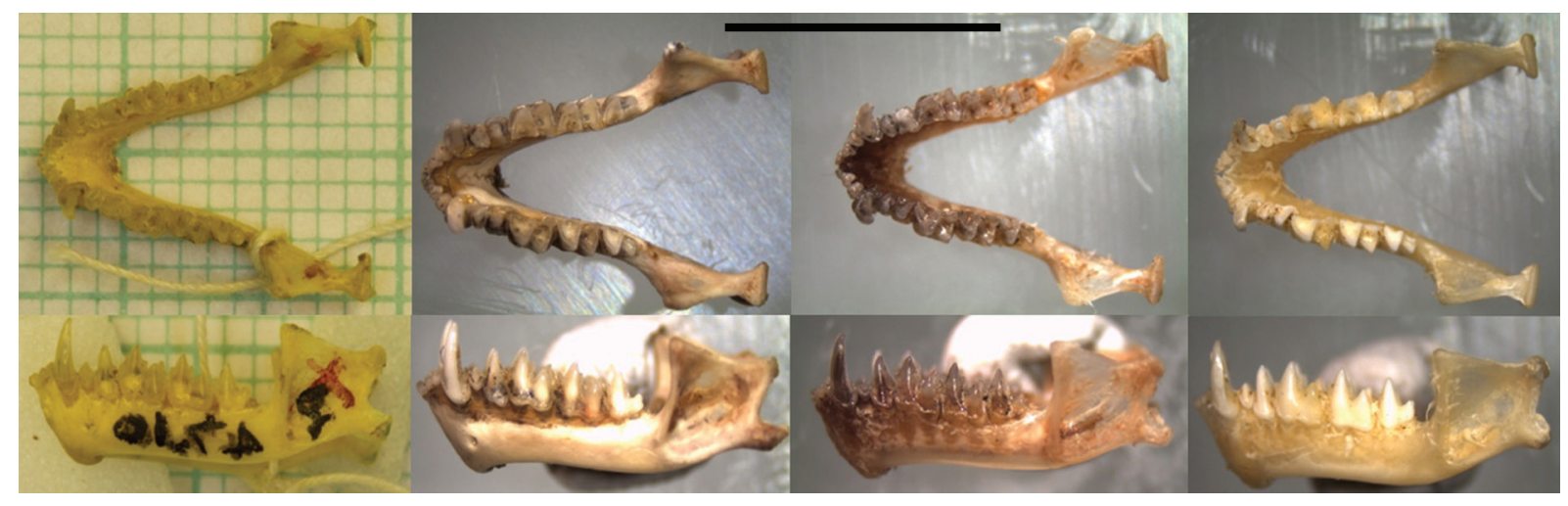

Fig. 6. Mandibles of the four known specimens of Glauconycteris superba Hayman, 1939 (upper row: dorsal view, lower row: lateral view). From left to right: holotype of G. s. sheila Hayman, 1947 (BMNH 47.10 , 9) [lateral picture flipped to fit the orientation of the other pictures], holotype of G. superba (RMCA 14765, ?), new specimen from Mbiye Island (RMCA a1.097-M-3153, §), and the specimen from Matonguiné (RMCA 97.077-M-7719, ठ̊). Scale bar $=1 \mathrm{~cm}$. 
Table 1. Craniodental and external measurements of Glauconycteris superba Hayman, 1939. Reference: 1. Randolph L. Peterson (courtesy of Judith Eger, pers. comm. 1 Nov. 2001; column 1). 2, 5, 7. FDV. 3. Rosevear (1965). 4. Hayman (1947). 6. Hayman (1939). 8. GCGT (field measurements). For measurement descriptions see text.

\begin{tabular}{|c|c|c|c|c|c|c|c|c|}
\hline & \multicolumn{2}{|c|}{$\begin{array}{c}\text { RMCA } \\
97.077-M-7719\end{array}$} & \multicolumn{3}{|c|}{$\begin{array}{c}\text { BMNH } \\
47.10\end{array}$} & \multicolumn{2}{|c|}{$\begin{array}{c}\text { RMCA } \\
14765\end{array}$} & $\begin{array}{c}\text { RMCA } \\
\text { a1.097-M-3153 }\end{array}$ \\
\hline Locality & \multicolumn{2}{|c|}{ Matonguiné } & \multicolumn{3}{|c|}{ Oda } & \multicolumn{2}{|c|}{ Pawa } & Mbiye \\
\hline Sex & \multicolumn{2}{|c|}{$\sigma^{\pi}$} & \multicolumn{3}{|c|}{ q } & \multicolumn{2}{|c|}{$?$} & $\sigma^{\lambda}$ \\
\hline Reference & 1 & 2 & 3 & 4 & 5 & 6 & 7 & 8 \\
\hline $\mathrm{Bm}$ & & & & & & & & 14.0 \\
\hline Tot & & & 112 & 112 & & 88 & & 91 \\
\hline H\&B & & & 63 & 63 & & 49 & & 66 \\
\hline Tail & & & 49 & 49 & & 39 & & 25 \\
\hline Ear & & 16.0 & & 13.0 & & 13.0 & & 13.4 \\
\hline Tra & & & & 7.0 & & 7.5 & & 5.5 \\
\hline FA & 44.7 & 44.5 & 46.0 & 47.0 & 46.2 & 47.5 & 47.6 & 42.6 \\
\hline WS & & & & & & & & 316.0 \\
\hline 2nd digit & & & & & & 44.5 & & \\
\hline Meta3 & 42.0 & 40.0 & 41.0 & & & 45.5 & 44.0 & \\
\hline 3ph1 & 18.7 & 18.5 & & & & 20.7 & 21.0 & \\
\hline 3 ph2 & & 25.0 & & & & & 24.5 & \\
\hline $3 p h 2+3$ & 22.4 & & & & & 24.3 & & \\
\hline Meta4 & 40.6 & 38.2 & & & & 44.0 & 43.1 & \\
\hline 4ph1 & 12.2 & 12.0 & & & & 13.3 & 13.3 & \\
\hline $4 \mathrm{ph} 2$ & 9.7 & 9.8 & & & & 10.8 & 10.2 & \\
\hline Meta5 & 35.5 & 33.2 & & & & 40.0 & 38.3 & \\
\hline 5ph1 & 7.6 & & & & & 8.2 & 8.5 & \\
\hline 5 ph2 & 7.0 & & & & & 8.2 & 7.5 & \\
\hline Tib & 20.0 & 19.0 & 21.0 & & & 21.3 & 20.3 & 18.6 \\
\hline Calcar & & & & & & c. 11.0 & & \\
\hline HFcu & & & & 10.0 & & 8.3 & & \\
\hline GLS & & 15.1 & & & 16.0 & & 15.3 & \\
\hline GLS+ & 16.4 & 15.6 & 16.5 & 16.1 & 16.5 & 16.2 & 15.9 & \\
\hline CBL & 15.4 & 14.9 & & 15.7 & 15.6 & 15.5 & 15.2 & \\
\hline PalLen Med & & 6.9 & & 7.7 & 5.6 & 6.5 & 6.9 & \\
\hline Mast & 9.5 & 8.8 & 9.9 & & 9.9 & 9.5 & 9.5 & \\
\hline Brain & 8.5 & 7.9 & & 9.1 & 9.0 & 8.5 & 8.3 & \\
\hline BcH & 6.7 & & & 9.6 & & 8.8 & & \\
\hline Zyg & 11.0 & & 11.9 & 11.9 & 12.0 & 11.0 & & \\
\hline C-C & 5.8 & 5.7 & & 6.2 & 6.2 & 6.0 & 5.7 & \\
\hline $\mathbf{M}^{3}-\mathbf{M}^{3}$ & 7.5 & 7.4 & 8.2 & 8.1 & 8.1 & 7.9 & 7.7 & \\
\hline C-M $\mathbf{M}^{3}$ & 5.8 & 5.6 & 6.2 & 6.2 & 6.0 & 6.0 & 5.8 & \\
\hline Ior & 4.7 & 4.7 & & 4.8 & 4.9 & 5.0 & & \\
\hline Mand & 11.6 & 11.4 & & 12.9 & 12.5 & 12.2 & 11.7 & \\
\hline $\mathrm{C}-\mathrm{M}_{3}$ & 6.4 & 6.3 & & & 6.7 & 6.6 & 6.4 & \\
\hline
\end{tabular}

the two other specimens, and - to a lesser extent - this also is the case for its tibia length (Tab. 3). Based on the skull measurements, however, this specimen had probably nearly reached its adult size.

In 1972, FDV examined the three specimens available at that time. He noticed that the genital area of the subadult type specimen from Pawa was damaged and that it could not be identified as "probably a male" as mentioned by Hayman (1939). However, his examination also revealed that the nipples were much 
Table 2. Craniodental measurements (rounded to nearest $0.1 \mathrm{~mm}$ ). For measurement descriptions see text.

\begin{tabular}{|c|c|c|c|}
\hline & $\begin{array}{c}\text { RMCA } \\
\text { 97.077-M-7719 }\end{array}$ & $\begin{array}{c}\text { RMCA } \\
14765\end{array}$ & $\begin{array}{c}\text { RMCA } \\
\text { a1.097-M-3153 }\end{array}$ \\
\hline Locality & Matonguiné & Pawa & Mbiye \\
\hline Sex & 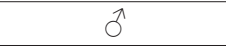 & $?$ & $\hat{0}$ \\
\hline Age & $\mathrm{ad}$ & subad & $\mathrm{ad}$ \\
\hline GLS & 14.8 & 14.9 & 14.8 \\
\hline GLS+ & 15.6 & 15.7 & 15.9 \\
\hline GLSC & 15.1 & 14.8 & 15.1 \\
\hline GLSC+ & 16.2 & 15.2 & 16.2 \\
\hline CBL & 14.6 & 15.3 & 15.1 \\
\hline CBL+ & 15.3 & 15.6 & 15.3 \\
\hline CBLC & 14.7 & 15.0 & 14.8 \\
\hline CBLC+ & 15.2 & 15.6 & 15.2 \\
\hline OCC & 12.4 & 12.9 & 12.3 \\
\hline IOR & 4.7 & & 4.9 \\
\hline ZYG & & & 11.0 \\
\hline MAST & 8.7 & 9.4 & 9.1 \\
\hline BRAIN & 8.5 & 8.6 & 8.3 \\
\hline ROSTR & 6.3 & 6.6 & 6.7 \\
\hline C-M $\mathbf{M}^{3}$ & 5.5 & 5.7 & 5.5 \\
\hline $\mathrm{C}-\mathrm{C}$ & 5.7 & 5.5 & 6.2 \\
\hline $\mathbf{M}^{3}-\mathbf{M}^{3}$ & 7.3 & 7.5 & 7.3 \\
\hline PalLen & & 6.1 & 5.7 \\
\hline POSTPAL & 5.2 & 5.0 & 5.6 \\
\hline PTB & 1.1 & 1.4 & 1.3 \\
\hline BBUL & 0.9 & 1.3 & 1.3 \\
\hline LBULW & 2.9 & 3.0 & 2.7 \\
\hline LBULL & 3.7 & 3.7 & \\
\hline RBULW & 3.3 & 2.8 & 3.1 \\
\hline RBULL & 3.8 & 3.7 & \\
\hline SHB & 8.0 & 8.8 & 8.3 \\
\hline SHBB & 6.8 & 6.7 & 6.5 \\
\hline SHRM & 5.5 & 5.7 & 5.5 \\
\hline MAND & 11.5 & 11.6 & 11.4 \\
\hline $\mathrm{C}-\mathrm{M}_{3}$ & 6.3 & 6.4 & 6.0 \\
\hline MAND2 & 8.9 & 9.0 & 9.4 \\
\hline CONCOR & 3.0 & 3.6 & 3.4 \\
\hline COR & 3.8 & 4.5 & 4.3 \\
\hline CONANG & 2.4 & 2.7 & 2.5 \\
\hline
\end{tabular}

better developed than those of the male specimen from Matonguiné and that, therefore, the holotype might represent a female rather than a male.

The forearm length of the type of G. superba agrees very well with that of the type of G. s. sheila (which is a female) and is larger than the specimens from Mbiye and Matonguiné (which are males; Tab. 1). This lends support to the suggestion that both types are indeed females. However, the limited number of available specimens does not allow a quantification of the intraspecific variation or sexual dimorphism, hence we are reluctant in assigning a sex to the type specimen of G. superba. If the type specimen is indeed a female, then this suggests that sexual dimorphism might also be present in G. superba, the 
Table 3. External measurements (rounded to nearest $0.1 \mathrm{~mm}$ ). For measurement descriptions see text.

\begin{tabular}{|l|c|c|c|}
\cline { 2 - 4 } \multicolumn{1}{c|}{} & $\begin{array}{c}\text { RMCA } \\
\text { 97.077-M-7719 }\end{array}$ & $\begin{array}{c}\text { RMCA } \\
\mathbf{1 4 7 6 5}\end{array}$ & $\begin{array}{c}\text { RMCA } \\
\text { a1.097-M-3153 }\end{array}$ \\
\hline Locality & Matonguiné & Pawa & Mbiye \\
\hline Sex & \multicolumn{1}{c|}{ ad } & subad & ad \\
\hline Age & 43.3 & 46.8 & 42.8 \\
\hline FA- & 43.9 & 47.3 & 43.1 \\
\hline FA+ & 37.5 & 42.0 & 37.7 \\
\hline Meta3 & 17.7 & 20.2 & 18.2 \\
\hline 3ph1 & 24.8 & 25.7 & 26.6 \\
\hline 3ph2+3 & 36.0 & 41.1 & 37.0 \\
\hline Meta4 & 11.8 & 13.3 & 11.7 \\
\hline 4ph1 & 8.1 & 9.1 & 8.9 \\
\hline 4ph2 & 32.6 & 36.4 & 32.9 \\
\hline Meta5 & 7.5 & 9.3 & 6.4 \\
\hline 5ph1 & 7.5 & 6.7 & 7.2 \\
\hline 5ph2 & $16.7 *$ & 19.0 & 16.8 \\
\hline Tib & 13.8 & 13.3 & 14.3 \\
\hline Ear & 6.7 & 5.3 & 6.2 \\
\hline Tra & 39.0 & $29.8 *$ & 30.7 \\
\hline Tail & 55.8 & & 53.8 \\
\hline H\&B & 6.2 & 6.7 & 6.5 \\
\hline Thumb & 9.7 & 8.4 & 9.7 \\
\hline HFcu & & & \\
\hline
\end{tabular}

* The tail length of the specimen from Pawa is an approximation as the genital area was removed during preparation of the specimen. The tail of the specimen from Mbiye could not be stretched completely. Both tibiae of the specimen from Matonguiné were damaged.

females being larger than the males, as was reported by Koopman (1971) for other species of the genus Glauconycteris.

\section{Discussion}

Currently known variation in pelage patterning and morphometric data of G. superba does not indicate a clear geographic signal and might suggest individual variation as found in other Glauconycteris-species. We concur with Rosevear (1965) that the characters differentiating G. s. sheila from the nominate form might represent the range of variation within populations, although the currently available sample size is probably too limited for a definite conclusion regarding the taxonomic status of G. s. sheila. As such, we tentatively consider G. s. sheila a synonym of the nominate form.

The four localities of G. superba are located in the tropical forest biome of West and Central Africa at elevations between $137 \mathrm{~m}$ and $775 \mathrm{~m}$ (Tab. 4, Fig. 7). Within this region, Matonguiné, Oda and Pawa are characterized by semi-deciduous forest at the periphery of evergreen lowland forest while Mbiye is located in the central Congo Basin. Today, land cover around the historic collection sites at Pawa, Oda and Matonguiné is a highly fragmented mosaic of secondary forests, farmland and human settlements as assessed with Google Earth (Oct. 2012), while Mbiye Island is covered by a mosaic of closed and secondary forest. Thus, contemporary satellite data on land cover show a mixed picture of both closed forests and mosaics of forest and croplands around the four localities (Tab. 4). However, more data are needed to evaluate whether G. superba critically depends on closed forests or to what extent this species tolerates habitat disturbance. The climate at the Kisangani weather station - taken as a proxy for Mbiye Island - is characterized by fairly high annual precipitation (mean: $1728 \mathrm{~mm}$, range: $1418-1915 \mathrm{~mm}$ ), 
Table 4. Geographic and climatic data for the localities where Glauconycteris superba Hayman, 1939 has been collected. GLC2000 = Global Land Cover 2000 (Mayaux et al. 2004); Precipitation = annual precipitation; $\mathrm{Tmin}=$ mean annual minimum temperature; $\mathrm{Tmax}=$ mean annual maximum temperature (Hijmans et al. 2005).

\begin{tabular}{|l|c|c|c|c|c|c|}
\hline \multicolumn{1}{|c|}{ Locality } & Coordinates & GLC2000 & $\begin{array}{c}\text { Elevation } \\
{[\mathbf{m}]}\end{array}$ & $\begin{array}{c}\text { Precipitation } \\
{[\mathbf{m m} / \mathbf{y e a r}]}\end{array}$ & $\begin{array}{c}\text { Tmin } \\
{\left[{ }^{\circ} \mathbf{C}\right]}\end{array}$ & $\begin{array}{c}\text { Tmax } \\
{\left[{ }^{\circ} \mathbf{C}\right]}\end{array}$ \\
\hline Pawa & $2^{\circ} 31^{\prime} 36^{\prime}{ }^{\circ}, 27^{\circ} 42^{\prime} 10^{\prime \prime} \mathrm{E}$ & Closed evergreen lowland forest & 775 & 2116 & 18.6 & 29.6 \\
\hline Mbiye island & $0^{\circ} 27^{\prime} 50^{\prime \prime} \mathrm{N}, 25^{\circ} 17^{\prime} 14 ” \mathrm{E}$ & Closed evergreen lowland forest & 413 & 1786 & 20.5 & 30.2 \\
\hline Oda & $5^{\circ} 55^{\prime} 23^{\prime \prime} \mathrm{N}, 00^{\circ} 599^{\prime} 42^{\prime \prime} \mathrm{W}$ & Mosaic Forest / Croplands & 137 & 1573 & 22.0 & 30.7 \\
\hline Matonguiné & $7^{\circ} 17^{\prime} 20^{\prime \prime} \mathrm{N}, 08^{\circ} 02^{\prime} 17^{\prime \prime} \mathrm{W}$ & Mosaic Forest / Croplands & 356 & 1986 & 18.3 & 30.9 \\
\hline
\end{tabular}

with two short dry seasons (December to February and June to July), and an average annual temperature varying between 23.5 and $25.3^{\circ} \mathrm{C}$ (Nshimba 2008). The other localities are also characterized by a humid, tropical climate and only Matonguiné differs in having one dry and one wet season as well as higher temperature fluctuations during the dry season (Fig. 8). Mean annual precipitation at the various localities is fairly high to high and ranges between $1573 \mathrm{~mm}$ and $2166 \mathrm{~mm}$. Compared to the two localities in DRC, the West African localities are more seasonal, and Matonguiné in particular has much lower monthly minimum temperatures during the dry season than the other sites (Fig. 8).

Many authors suggest that striped or spotted colouration patterns in bats improve their camouflage when roosting in foliage, e.g. Yalden \& Morris (1975) for Glauconycteris, Hall \& Richards (1979) for

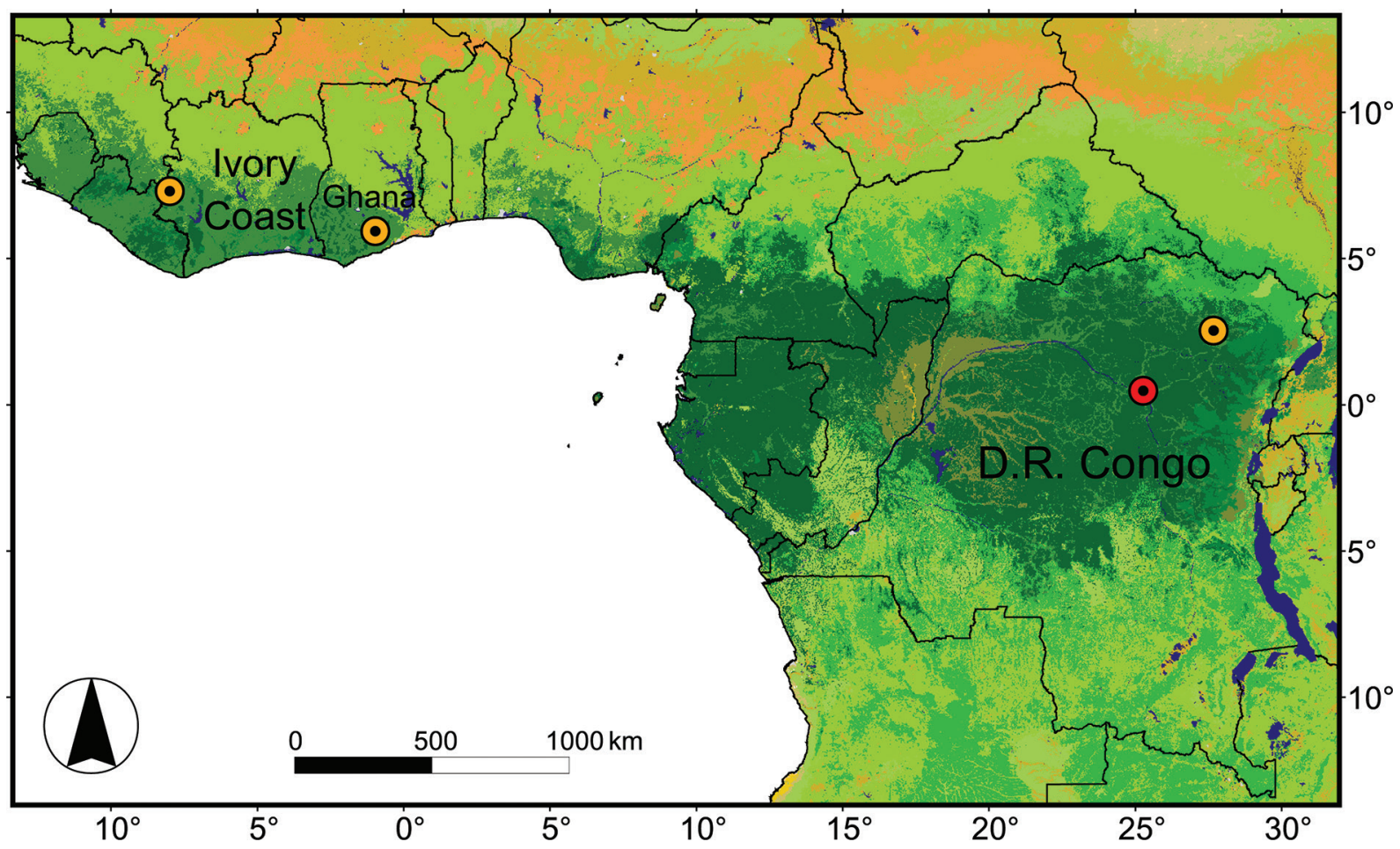

Fig. 7. Distribution map of G. superba showing the four currently known records from Ivory Coast, Ghana, and DRC; red dot: Mbiye Island. Land cover data from GLC2000 (Mayaux et al. 2004). 
Nyctimene Borkhausen, 1797, Hill \& Smith (1984) for Euderma H. Allen, 1892, Lim \& Dunlop (2008) for New World emballonurids, and Santana et al. (2011) for bats in general. Such colouration is likely to provide protection from predators in their day roosts and probably also lowers the chances of being detected by researchers, but this would not influence the capture success of techniques such as shooting, mist netting or harp trapping. The low number of G. superba in museum collections might thus indicate that it is indeed a very rare species, or that we simply do not know yet where to look for it.

In the IUCN Red List of Threatened Species, G. superba is currently ranked as "Least Concern" (LC; Fahr et al. 2008). The species had been ranked as "Vulnerable" (VU) during the initial workshop of the Global Mammal Assessment in 2004 but was later downgraded to "Least Concern" due to its wide distribution, presumed large population, and because it was considered unlikely to be declining fast enough to qualify for listing in a more threatened category. However, G. superba is either very rare or unusually difficult to record as evidenced by the four currently known specimens, which were collected over a period of 74 years between 1938 and 2012, with collection intervals of eight, 26 and 40 years, respectively.
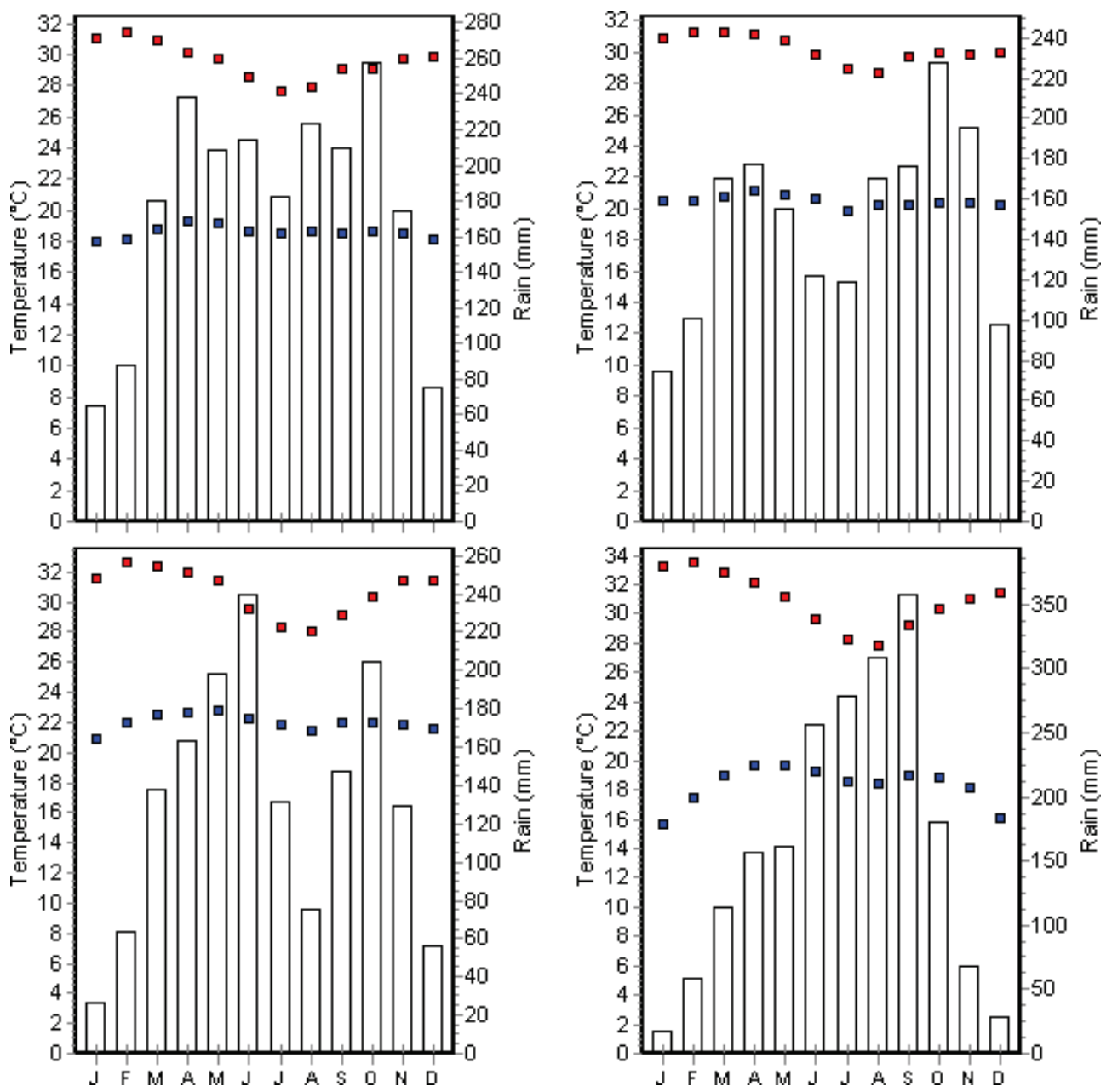

Fig. 8. Climate graphs for Pawa (upper left), Mbiye (upper right), Oda (lower left), and Matonguiné (lower right). Upper line of squares: mean monthly maximum temperature, lower line of squares: mean monthly minimum temperature, bars: mean monthly precipitation (plotted using DIVA-GIS, data from Hijmans et al. 2005). 
In fact, the large intervals between previous captures and the long time elapsed since the last record (1972) could have led to the erroneous conclusion that G. superba had become extinct. Fisher \& Blomberg (2012), who examined the extinction probability of mammals with a restricted number of sighting records, reported that the interval between last sightings and estimated extinction for most mammals was between 1 and 31 years, with a mean of 8.8 years. This interval was clearly exceeded in $G$. superba prior to our rediscovery, which stresses the need for more surveys and research effort to determine the status of elusive small mammals such as G. superba.

Although the maximum distance of ca. $4000 \mathrm{~km}$ between the most distant records (Matonguiné and Pawa) indicates a large extent of occurrence, the extremely low number of known localities recorded over a long period might indicate very specific habitat requirements and possibly a very restricted area of occupancy. Moreover, the specimens from Pawa, Oda and Matonguiné originated from forest areas that are today heavily degraded and fragmented, especially those in West Africa (Chatelain et al. 2004; Duveiller et al. 2008), and it is currently unknown whether G. superba still occurs at, or near these localities. Given these uncertainties, we believe that ranking this species as "Data Deficient" (DD) is more appropriate under a precautionary principle, and that more data are required for an informed assessment of the threat status of this species. Furthermore, available material should be sequenced to assess whether the taxon, as currently conceived, comprises cryptic species despite the morphological agreement of the currently known specimens that were collected over a large distribution range.

\section{Acknowledgements}

We would like to thank Wim Wendelen (RMCA) for extracting the skull of the new specimen and for taking the skull photos in the Tervuren collection, and René Schaerlaeken for the drawing of the head of the Matonguiné specimen. The efforts by Judith Eger (Royal Ontario Museum, Toronto) and Wim Bergmans (Zoological Museum Amsterdam) that helped to locate the "lost" specimen from Matonguiné at the University of Antwerp are highly appreciated. We further thank Teresa Kearney and Ernest Seamark (Ditsong National Museum of Natural History [formerly Transvaal Museum]) as well as the Natural History Museum, London for providing the photos of the type specimen of G. superba sheila. Thanks to Charles Balekage, Marc Boketshu, Prosper Kakule, Japhet Kasereka, Joseph Kussa, John Mbusa and Charles Andabathi, students at the University of Kisangani, for their contribution to regular sampling of bats. The LEGERA field work was supported by a CIFOR scholarship from the European Union (REAFOR program: GCP/DRC/036/EC), for which we thank their respective directors: Dr. Nasi, and Prof. Mate and Ndjele. Emmanuel Gilissen is thanked for his hospitality during GCGT's stay at the RMCA, which was supported by a travel grant from VLIR-UOS and ABIC (DGD).

\section{References}

Chatelain C., Dao H., Gautier L. \& Spichiger R. 2004. Forest cover changes in Côte d'Ivoire and Upper Guinea. In: Poorter L., Bongers F., Kouamé F.N. \& Hawthorne W.D. (eds) Biodiversity of West African Forests. An Ecological Atlas of Woody Plant Species: 15-32. CABI Publishing, Wallingford. http:// dx.doi.org/10.1079/9780851997346.0015

Duveiller G., Defourny P., Desclée B. \& Mayaux P. 2008. Deforestation in Central Africa: Estimates at regional, national and landscape levels by advanced processing of systematically-distributed Landsat extracts. Remote Sensing of Environment 112 (5): 1969-1981. http://dx.doi.org/10.1016/j.rse.2007.07.026

Fahr J. 2013. Glauconycteris superba Pied butterfly bat. In: Happold M. \& Happold D.C.D. (eds) The Mammals of Africa. Vol. 4: Hedgehogs, Shrews and Bats: 575-576. Bloomsbury, London.

Fahr J., Jacobs D., Cotterill F.P.D. \& Taylor P.J. 2008. Glauconycteris superba. In: IUCN (2012) IUCN Red List of Threatened Species. Version 2012.1. Available from http://www.iucnredlist.org [accessed 3 Sep. 2012]. 
Fisher D.O. \& Blomberg S.P. 2012. Inferring extinction of mammals from sighting records, threats, and biological traits. Conservation Biology26(1):57-67.http://dx.doi.org/10.1111/j.1523-1739.2011.01797.x

Hall L.S. \& Richards G.C. 1979. Bats of Eastern Australia. Queensland Museum booklet 12, Queensland Museum, Brisbane.

Hayman R.W. 1939. Two new mammals from the Belgian Congo. Annals and Magazine of natural History 113 (14): 219-224. http://dx.doi.org/10.1080/03745481.1939.9723594

Hayman R.W. 1947 [for 1946]. A new race of Glauconycteris superba from West Africa. Annals and Magazine of natural History 1113 (104): 547-550. http://dx.doi.org/10.1080/00222934608654576

Hayman R.W. \& Hill J.E. 1971. Order Chiroptera. In: Meester J. \& Setzer H.W. (eds) The Mammals of Africa. An Identification Manual Part 2: 1-73. Smithsonian Institution Press, Washington.

Hayman R.W., Misonne X., Verheyen W.N. 1966. The bats of the Congo and of Rwanda and Burundi. Annales du Musée royal de l'Afrique Centrale (série Zoologie) 154, Musée Royal de l'Afrique Centrale, Tervuren.

Hijmans R.J., Cameron S.E., Parra J.L., Jones P.G. \& Jarvis A. 2005. Very high resolution interpolated climate surfaces for global land areas. International Journal of Climatology 25 (15): 1965-1978. http:// dx.doi.org/10.1002/joc. 1276

Hill J.E. \& Smith J.D. 1984. Bats: A Natural History. University of Texas Press, Austin.

Koopman K.F. 1971. Taxonomic notes on Chalinolobus and Glauconycteris (Chiroptera, Vespertilionidae). American Museum Novitates 2451: 1-10. Available from http://hdl.handle.net/2246/2660

Lejoly J., Ndjele L. \& Geerinck D. 2010. Catalogue-flore des plantes vasculaires des districts de Kisangani et de la Tshopo (RD Congo). $4^{\text {th }}$ Edition. D.J.P. de Blaay, Durbuy, Belgium.

Lim B.K. \& Dunlop J.M. 2008. Evolutionary patterns of morphology and behavior as inferred from a molecular phylogeny of New World emballonurid bats (Tribe Diclidurini). Journal of Mammalian Evolution 15 (2): 79-121. http://dx.doi.org/10.1007/s10914-007-9068-0

Mayaux P., Bartholomé E., Fritz S. \& Belward A. 2004. A new land-cover map of Africa for the year 2000. Journal of Biogeography 31 (6): 861-877. http://dx.doi.org/10.1111/j.1365-2699.2004.01073.x

Nowak R.M. 1999. Walker's Mammals of the World. Vol. 1. $6^{\text {th }}$ Edition. Johns Hopkins University Press, Baltimore.

Nshimba H.S. 2008. Etude floristique, écologique et phytosociologique des forêts de l'île Mbiye à Kisangani, RD Congo. PhD thesis, Université Libre de Bruxelles, Brussels, Belgium. Available from http://theses.ulb.ac.be/ETD-db/collection/available/ULBetd-02012008-181253/ [accessed 29 Oct. 2012].

Peterson R.L. \& Smith D.A. 1973. A new species of Glauconycteris (Vespertilionidae, Chiroptera). Life Science Occasional Papers 22: 1-9. http://dx.doi.org/10.5962/bhl.title.60686

Rambaldini D.A. 2010. Glauconycteris variegata (Chiroptera: Vespertilionidae). Mammalian Species 42 (1): 251-258. http://dx.doi.org/10.1644/870.1

Rosevear D.R. 1965. The Bats of West Africa. Trustees of the British Museum (Natural History), London.

Santana S.E., Dial T.O., Eiting T.P. \& Alfaro M.E. 2011. Roosting ecology and the evolution of pelage markings in bats. PLoS ONE 6 (10), e25845. http://dx.doi.org/10.1371/journal.pone.0025845

Yalden D.W. \& Morris P.A. 1975. The Lives of Bats. David \& Charles, Newton Abbot. 
Manuscript received: 5 November 2012

Manuscript accepted: 24 January 2013

Published on: 10 April 2013

Topic editor: Rudy Jocqué

Desk editor: Charlotte Thionois

Printed versions of all papers are also deposited in the libraries of the institutes that are members of the EJT consortium: Muséum National d'Histoire Naturelle, Paris, France; National Botanic Garden of Belgium, Meise, Belgium; Royal Museum for Central Africa, Tervuren, Belgium; Natural History Museum, London, United Kingdom; Royal Belgian Institute of Natural Sciences, Brussels, Belgium; Natural History Museum of Denmark, Copenhagen, Denmark. 


\section{Appendix: Details of available Glauconycteris superba specimens}

DEMOCRATIC REPUBLIC OF THE CONGO: Pawa, 30 mi ENE Medje (Hayman 1939, Hayman et al. 1966; RMCA 14765, leg. Dr. Albert Dubois [received 8 Aug. 1938], subad ?, alc \& skull, holotype G. s. superba); Mbiye Island (this study; RMCA a1.097-M-3153, leg. Guy-Crispin Gembu Tungaluna, collected 19 Feb. 2012, original number CHIM 012, ad $\hat{\partial}$, alc \& skull).

GHANA: Oda (Hayman 1947, Rosevear 1965; BMNH 47.10, leg. George Soper Cansdale, collected 6 Dec. 1946, original number 807, ad + , skin \& skull, holotype G. s. sheila).

IVORY COAST: Matonguiné (Peterson \& Smith 1973; RMCA 97.077-M-7719, leg. Louis Bellier, collected 24 Jan. 1972, original number A9396, ad ô, alc \& skull). 